\title{
Analisis Rekonstruksi Penyusunan Laporan Keuangan Masjid (Studi Kasus pada Masjid Agung Baiturrahman Banyuwangi)
}

\author{
(Reconstruction Analysis Of Preparation Of Mosque Financial Statements \\ (The Case Study At Baiturrahman Banyuwangi Great Mosque))
}

\author{
Arif Hidayatullah", Agung Budi Sulistiyo, Nur Hisamuddin \\ Jurusan Akuntasi, Fakultas Ekonomi dan Bisnis, Universitas Jember (UNEJ) \\ Jln. Kalimantan 37, Jember 68121 \\ E-mail:mr.hidayat_arief@yahoo.com
}

\begin{abstract}
Abstrak
Masjid merupakan salah satu organisasi nirlaba (non profit oriented) dalam bidang keagamaan yang dalam menjalankan aktivitasnya, dengan mengelola sumber daya yang dimilikinya dan sumber daya yang diperoleh dari masyarakat secara sukarela dan ikhlas sesuai dengan Pernyataan Standar Akuntansi Keuangan (PSAK) 45 tentang Organisasi Nirlaba, bahwa organisasi nirlaba juga harus dan berhak untuk membuat laporan keuangan dan melaporkan kepada para pemakai laporan keuangan. Masjid harus membuat laporan keuangan yang akurat dan memberikan informasinya kepada pengguna laporan keuangan tersebut yaitu para donatur masjid. Untuk dapat membuat laporan keuangan masjid yang akurat diperlukan penerapan akuntansi. Akuntansi merupakan suatu kegiatan yang dilakukan untu menghasilkan sautu sistem informasi berupa laporan keuangan. Dengan demikian, masjid memerlukan peranan akuntansi sebagai alat bantu untuk proses pengelolaan, pencatatan, pengitikhsaran, dan pelaporan transaksi keuangan yang selalu berpedoman dengan PSAK 109 dan PSAK 45 yang ditetapkan oleh Ikatan Akuntan Indonesia (IAI) yang akhirnya akan menghasilkan laporan keuangan yang lebih transparan dan akuntabel.
\end{abstract}

Kata kunci: Laporan keuangan masjid, Masjid, Organisasi Nirlaba, Laporan Keuangan Masjid, PSAK 109, PSAK45.

\begin{abstract}
The mosque is one of the non-profit oriented organizations in the field of religion in carrying out its activities, by managing its resources and resources derived from the community voluntarily and sincerely in accordance with the Statement of Financial Accounting Standards (PSAK) 45 on Nonprofit Organizations, That non-profit organizations should also and are entitled to make financial reports and report to users of financial statements. Mosques must make accurate financial statements and provide information to users of these financial statements ie the donors of the mosque. To be able to make accurate mosque financial statements required the application of accounting. Accounting is an activity undertaken untu produce sautu information system in the form of financial statements. Thus, mosques require the role of accounting as a tool for the process of managing, recording, interpreting, and reporting financial transactions that always guided by PSAK 109 and PSAK 45 set by the Indonesian Institute of Accountants (IAI) which will ultimately produce more transparent financial statements and Accountable.
\end{abstract}

Keywords: Financial Statement of Mosque, Mosque, Nonprofit Organization,, PSAK 109, PSAK 45.

\section{Pendahuluan}

Tingginya tingkat ketidak pastian dan ketidak stabilan lingkungan yang dihadapi oleh berbagai organisasi memerlukan sebuah sistem perencanaan yang baik. Peranan akuntansi dalam segi pengelolaan keuangan sebuah organisasipun semakin disadari oleh berbagai pihak, baik organisasi yang berorientasi pada laba maupun non-laba (nirlaba). Menurut Jusup (2005) organisasi nirlaba merupakan organisasi yang tidak mencari laba seperti organisasi keagamaan, yayasan atau lembaga pendidikan. Walaupun organisasi semacam ini tidak mencari laba tetapi mereka tetap berurusan dengan soal-soal keuangan karena mereka mempunyai anggaran, membayar tenaga kerja, membayar listrik dan sewa, serta urusan-urusan keuangan lainnya. Disamping itu, terdapat karateristik khusus organisasi nirlaba dalam memperoleh sumber daya yang dibutuhkan untuk menjalankan aktivitas operasionalnya. Organisai nirlaba memperoleh sumber daya dari sumbangan para penyumbang yang tidak mengharapkan pembayaran

\footnotetext{
* Corresponding author
}

kembali atau pengembalian manfaat ekonomi yang sebanding dengan jumlah sumber daya yang diberikan (IAI, 2015). Karakteristik khusus ini menimbulkan jenis transaksi, siklus operasi, pola pengelolaan keuangan, perlakuan akuntansi dan kebutuhan pelaporan keuangan yang berbeda.

Masjid merupakan salah satu organisasi nirlaba (non profit oriented) dalam bidang keagamaan yang dalam menjalankan aktivitasnya, dengan mengelola sumber daya yang dimilikinya dan sumber daya yang diperoleh dari masyarakat secara sukarela dan ikhlas sesuai dengan Pernyataan Standar Akuntansi Keuangan (PSAK) 45 tentang Organisasi Nirlaba, bahwa organisasi nirlaba juga harus dan berhak untuk membuat laporan keuangan dan melaporkan kepada para pemakai laporan keuangan. Masjid harus membuat laporan keuangan yang akurat dan memberikan informasinya kepada pengguna laporan keuangan tersebut yaitu para donatur masjid. Untuk dapat membuat laporan keuangan masjid yang akurat diperlukan penerapan akuntansi. Dengan penerapan akuntansi yang baik dapat membantu dalam melakukan penyusunan laporan keuangan masjid yang baik. (Andarsari, 
2016).

Menurut Dewan Masjid Indonesia (DMI) terdapat tiga fungsi masjid, pertama masjid sebagai ibadah (mahdlah) juga merupakan tempat untuk beribadah secara luas (Gairu Madhlah) selama dilakukan dalam batas-batas syariah. Ketika Nabi SAW. memilih masjid sebagai langkah pertama membangun masyarakat madani, konsep masjid bukanlah hanya sebagai tempat sholat, atau tempat berkumpulnya kelompok masyarakat (kabilah) tertentu, tetapi masjid sebagai majelis untuk memotivasi atau mengendalikan seluruh masyarakat (Pusat pengendalian masyarakat). Secara konseptual masjid juga disebut sebagai Rumah Allah (Baitullah) atau bahkan rumah masyarakat (bait al jami'). (http://www.siperubahan.com/read/436/Ketika-Masjid-

Membutuhkan-Sentuhan-Para-Ekonom-Syariah). Melihat secara umum perkembangan masjid di masa sekarang, terutama dalam hal kepengurusan identik dengan seorang Imam, muadzin, khatib, dan pengurus lain yang sering disebut juga dengan ta'mir masjid. Ta'mir biasanya adalah orang yang sudah tua dan tidak memiliki latar belakang keilmuan yang cukup untuk mengelola keuangan secara profesional. Hal ini menimbulkan persoalan ketika dana masjid yang diperoleh dari infaq atau sumbangan para donatur dikelola secara apa adanya tanpa melalui proses pencatatan keuangan yang semestinya. (Andarsari, 2016). Permasalahan lain yang seringkali muncul yaitu masih banyaknya masjid yang tidak mencatat secara rinci pemasukan dan pengeluaran kas, biasanya hanya dicatat sebatas penerimaan dan pengeluaran kas tanpa merinci sumber pemasukan kas dan penggunaan kas masjid untuk apa saja, sehingga terkadang hal ini menimbulkan kecurigaan di kalangan masyarakat.

Transparansi dan Akuntanbilitas merupakan suatu hal yang sangat penting dan sangat diperlukan dalam organisasi atau lembaga publik, swasta maupun lembaga keagamaan. Semua aktivitas lembaga baik publik maupun swasta selalu dituntut transparan dan akuntabel. Kehidupan keagamaan seakan menjadi dimensi lain yang tidak memerlukan transparansi dan akuntabilitas secara langsung dalam bentuk pelaporan akuntansi. Padahal transparansi dan akuntabilitas sangat diperlukan dalam pengelolaan laporan keuangan entitas nirlaba (masjid). Dengan keterbukaan, akuntabilitas atas laporan keuangan masjid maka akan berdampak positif kepada para stakeholders atau masyarakat sekitar terhadap pengelolaan dan manajemen keuangan masjid. Namun kenyataannya masih banyak penerapan laporan keuangan dilembaga masjid yang masih belum menerapkan transparansi, akuntabilitas dalam penyusunan laporan keuangan sehingga menjadi perhatian khusus dalam kajian praktik ini. (Wijangsongko, 2014)

Oleh karena itu, masjid sebagai salah satu organisasi nirlaba (non profit oriented) harus benar-benar dapat mempertanggungjawabkan segala informasinya karena menyangkut kepentingan publik. Salah satu bentuk pertanggungjawabannya yaitu dengan adanya transparansi dan akuntanbilitas tentang pengelolaan laporan keuangan dan penyusunan laporan keuangan masjid yang baik. Maka dari itu diperlukan tenaga pengelola keuangan masjid yang benarbenar amanah, mengetahui tentang praktik keuangan (akuntansi), serta mampu mempertanggungjawabkan informasi. Hal ini dapat meminimalisir kesenjangan informasi keuangan antara lembaga masjid dengan masyarakat publik sebagai penaman sumber dananya. (Andikawati, 2014)

Sumber dana yang diperoleh oleh masjid dapat berasal dari kotak amal masjid, donasi, zakat, infak dan shodaqoh dari masyarakat. Dari sumber dana tersebut pengelola keuangan masjid yaitu ta'mir seharusnya dapat menyajikan laporan keuangan masjid dengan baik dan mampu menyediakan informasi yang transparan dan akuntabel. Karena biasanya yang kita ketahui laporan keuangan masjid hanya disajikan setiap satu minggu sekali pada saat sholat jumat. Maka dari itu pengurus masjid diharapkan mampu melaporkan informasi keuangan masjid secara terbuka kepada publik sehingga dapat memberikan informasi kepada masyarakat secara terbuka dan masyarakat merasa puas atas pengelolaan keuangan masjid tersebut. Oleh karena itu dari hasil penelitian yang dilakukan penulis, diharapkan kepada pengelola/pengurus masjid untuk mampu mempublikasikan transparansi dana dan penyusunan laporan keuangannya. Dengan adanya transparansi dana dan pengelolaan keuangan masjid maka akan memberikan ketenangan kepada masyarakat dan percaya ketika akan menyumbangkan uangnya atau dananya. (Andikawati, 2014)

Pengelolaan keuangan masjid merupakan hal yang sangat viral untuk diteliti dan dievaluasi khususnya dalam hal penyajian dan penyusunan laporan keuangan. Dalam penyusunan laporan keuagan masjid Ikatan Akuntan Indonesia (IAI) mempunyai peranan yang sangat penting dengan menerbitkan PSAK 109 dan PSAK 45. PSAK 109 sendiri mengatur tentang akuntansi zakat, infaq, shodaqoh yang biasanya ini merupakan sumber dana utama bagi masjid. Sedangkan PSAK 45 mengatur tentang pelaporan keuangan khusunya untuk organisisasi nirlaba salah satunya masjid. Organisasi nirlaba ini mendapat sumber dananya berasal dari dana hibah, donasi, infaq shodaqoh dari masyarakat umum yang memberikan dananya. Selain itu organisasi nirlaba ini juga menjalankan aktivitasnya tanpa mengharapkan laba (non profit oriented) dan semata-mata hanya untuk kepentingan lembaga tersebut (masjid).

Salah satu aspek penting keberlangsungan pengelolaan masjid yang baik adalah adanya dana untuk operasional masjid, sebab masjid tidak hanya untuk dibangun tapi juga perlu dana untuk menopang kegiatan kegiatan masjid. Maka sudah menjadi tugas dan tanggung jawab para pengurus (takmir) masjid untuk memikirkan dan mencari dana untuk kemakmuran masjid (Ayub et al, 2005:57).Masjid adalah lembaga publik yang sumber dananya berasal darimasyarakat. Untuk itu, pengurus masjid harus melaporkan pemasukan danpengeluaran dana masjid, agar jamah semakin percaya bahwa dana merekabenar-benar digunakan untuk kepentingan masjid (Yani, 2009:162).

Sumber pendapatan masjid biasanya terdiri dari Zakat, Infaq, Shodaqoh dan Waqof dan sumber pengeluaran masjid terdiri dari biaya rutin (listrik,air), biaya kebersihan,biaya kegiatan Islami yaitu kegiatan yang dilakukan untuk memperingati hari-hari besar Islam Maulid Nabi SAW, Ramadhan, dan lain sebagainya. Dalam mempertanggungjawabkan sumber pendapatan dan pengeluaran tersebut pengurus (takmir) masjid dituntut untuk mencatat, menyusun dan mengelola keuangan tersebut dengan baik, kemampuan pengelolaan keuangan yang baik merupakan salah satu bentuk bahwa 
pengurus (takmir) masjid merupakan orang yang amanah dan bertanggung jawab. Selain itu sebagaimana yang dipaparkan oleh Kurniasari (2011) bahwa pengelolaan keuangan masjid yang baik merupakan faktor utama dalam upaya menjaga keberlangsungan dan kemakmuran masjid.

Dalam Pengelolaan keuangan dan sumber daya masjid harus memenuhi tiga kriteria yakni: efisien, efektif dan bertanggung jawab (Pralebda, 2013). Kriteria pertama, efisien. Efisien mengandung makna bahwa pengelolaan keuanganmasjid harus sehemat mungkin. Termasuk dari sikap efisien pengurus masjid adalah dengan menggunakan atau membelankajakan dana masjid untuk kebutuhan dan kegiatan-kegiatan sosial masjid yang memang telah dianggarkan sebelumnya.

Kriteria kedua adalah efektif. Efektif adalah sikap yang menggunakan sumber daya masjid seoptimalmungkin untuk mencapai tujuan. contoh dari sikap efektif pengurus masjid adalah dengan memperhatikan biaya yang digunakan untuk pemeliharan atau perbaikan sarana dan prasarana yang ada, misalnya saja pendingin ruangan, hal tersebut dilakukan guna menunjang kenyamanan para jamaah dalam beribadah.

Kriteria ketiga adalah bertanggung jawab. Bertanggung jawab dalamkonteks ini adalah kemampuan pengurus masjid dalam memberikanpertanggungjawaban kepada jamaah mengenai segala aktivitas yang telahdilakukan. Pengurus masjid harus mampu mempertanggungjawabkan khususnya dalam hal keuangan, dengan mencatat, menyusun dan melaporkan segala aspek informasi mengenai aktifitas maupun keuangan yang memang benar-benar dapat dipertanggungjawabkan. Megingat bahwa pertanggungjawaban bukan hanya sebatas kepada sesama ataupun alam, melainkan pertanggungjawaban yang utama adalah kepada Allah SWT.

Berdasarkan latar belakang diatas, maka dapat ditemukan dua rumusan masalah yaitu bagaimana laporan keuangan pada lembaga Masjid Agung Baiturrahman Banyuwangi dan bagaimana rekonstruksi penyusunan laporan keuangan masjid kedalam PSAK 109 dan PSAK 45. Kemudian tujuan yang dapat diambil dari kedua rumusan masalah tersebut yaitu mengkaji serta menganalisis penerapan laporan keuangan yang ada pada Masjid Agung Baiturrahman Banyuwangi serta merekonstruksi laporan keuangan Masjid sesuai dengan PSAK 109 dan PSAK 45.

\section{Metode}

\section{Rancangan Penelitian}

Jenis penelitian yang digunakan adalah penelitian kualitatatif yang akan dilaksanakan di Majis Agung Baiturrohman di Kabupaten Banyuwangi. Penelitian kualitatif adalah penelitian yang dimaksud untuk memahami fenomena tentang apa yang dialami oleh subyek penelitian yang menekankan pada pemahaman mengenai masalahmasalah dalam kehidupan sosial berdasarkan kondisi realitas atau natural setting yang holistik, kompleks dan rinci (Nur Indriantoro 2014:12)

\section{Jenis dan Sumber Data}

Dalam penelitian ini menggunakan jenis primer dan sekunder yang diambil dari objek penelitian. Dalam penelitian ini data primer yaitu melalui wawancara langsung kepada pengurus/ pengelola masjid atau yang biasa disebut ta'mir masjid dan juga bendahara masjid dan untuk data sekunder diperoleh dari laporan keuangan yang terdapat di Masjid Agung Baiturrahman tahuan 2016.

\section{Metode Pengumpulan Data}

\section{Data Primer}

Teknik pengumpulan data primer yaitu data yang diperoleh melalui kegiatan penelitian langsung ke lokasi penelitian untuk mencari data-data yang lengkap dan berkaitan denganmasalah yang diteliti (Indriantoro dan Supomo (2014:146). Teknik ini dilakukan melalui :

\section{a. Wawancara}

Metode pengumpulan data dengan mengajukan pertanyaanpertanyaan secara langsung dan memiliki relevansi terhadap masalah yang berhubungan dengan penelitian. wawancara dapat dilakukan langsung kepada pengurus/ pengelola masjid atau yang biasa disebut ta'mir masjid dan juga bendahara masjid.

\section{b. Observasi}

Teknik pengumpulan data dengan cara mengamati secara langsung terhadap objek penelitian kemudian mencatat gejala-gejala yang ditemukan di lapangan untuk melengkapi data-data yang diperlukan sebagai acuan untuk yang berkaitan dengan permasalahan penelitian.

\section{Data sekunder}

Data sekunder (Indriantoro dan Supomo (2014:147) adalah data yang diperoleh baik yang belum di oleh maupun yang telah diolah, baik dalam bentuk angka maupun uraian. Untuk data sekunder diperoleh dari laporan keuangan yang terdapat di Masjid Agung Baiturrahman tahuan 2016.

\section{Teknik Analisis Data}

Data ini diperoleh dari lembaga masjid di Masjid Agung Baiturrahman Banyuwangi. Setelah data-data diperoleh maka selanjutnya akan diolah kemudian dilakukan analisa. Analisa data adalah cara atau langkah-langkah untuk mengolah data primer atau sekunder, yang bermanfaat bagi peneliti guna mencapai tujuan akhir penelitian. Penelitian ini menggunakan analisa kualitatif dengan cara mendeskripsikan atau menggambarkan keadaan objek penelitian yang sesungguhnya untuk mengetahui dan menganalisa tentang permasalahan yang dihadapi oleh objek penelitian kemudian ditandingkan dengan standart yang ada pada saat ini selanjutnya dideskripsikan bagaimana laporan keuangan di lembaga masjid kaitannya dengan bagaimana laporan keuangan lembaga masjid berdasarkan PSAK 45 dan PSAK 109 yang meliputi analisa terhadap pengakuan, pengukuran, pengungkapan dan pelaporannya.

Analisa data dimulai dengan mengumpulkan data primer yang diperoleh dengan metode wawancara terhadap pihak yang terkait kemudian dikembangkan dari analisa berdasarkan data sekunder yang berupa laporan keuangan. Langkah-langkah analisa data yang akan dilakukan oleh peneliti sebagai berikut:

1. Menganalisa tentang laporan keuangan yang terjadi pada lembaga masjid saat muzzaki memberikan zakat, 
infak/shodaqoh kepada mustahiq, dan dana yang dimiliki oleh lembaga masjid dipergunakan untuk keperluan apa saja.

2. Merekonstruksi laporan keuangan masjid dalam hal penyajian laporan keuangan berdasarkan PSAK 45 dan PSAK 109.

\section{Hasil dan Pembahasan}

\section{Ketentuan PSAK Pada Laporan Keuangan Masjid}

Masjid merupakan salah satu bentuk organisasi nirlaba atau organisasi yang tidak mengharapkan laba (non profit oriented). Karena itu, masjid sebagai sarana peribadatan dan kegiatan ummat memerlukan pelaporan keuangan yang efektif, hal ini di karenakan untuk menunjang kegiatan peribadatan dan keagamaan. Dalam organisasi ini banyak sekali dana-dana yang terkumpul dan sekian banyaknya penyumbang baik berupa zakat, infaq dan shodaqoh dan juga banyak dana yang sudah disalurkan untuk berbagai kegiatan di dalam masjid seperti renovasi masjid, biaya-biaya listrik air, guru ngaji, dan santunan sosial. Mengingat banyaknya dana yang ada di masjid maka perlu adanya laporan keuangan yang efektif dan relevan sehingga bisa dipertanggungjawabkan kepada masyarakat, donatur, maupun pemerintah. Dalam halnya bendahara masjid melaporkan kegiatan dananya melalui laporan keuangan sederhana dalam bentuk perbulan maupun pertahun yang berisi tentang rincian penerimaan dan rincian pengeluaran yang nantinya saldo dari kas bulan lalu akan di tambahkan dengan jumlah rincian penerimaan dan dikurangkan dengan rincian pengeluaran yang nantinya akan menghasilkan saldo untuk bulan ini. Dalam penerapan PSAK 109 ataupun PSAK 45 mengingat masjid adalah termasuk organisasi nirlaba dan masjid merupakan sumber dananya berasal dari zakat, infaq dan shodaqoh laporan yang dibuat oleh masjid agung baiturrahman masih kurang ideal karena laporan keuangan yang didapat penulis hanya sebatas laporan keuangan sederhana meskipun sudah menerapkan nomer rekening untuk setiap transaksi. Setelah menganalisis laporan keuangan masjid, laporan keuangan berdasarkan PSK 109 lebih cocok untuk diterapkan untuk masjid daripada PSAK 45, karena akun-akun yang ada dalam PSAK 109 hampir sama dengan laporan keuangan masjid sederhana.

\section{Proses Pelaporan Keuangan Masjid Agung Baiturrahman Berdasarkan PSAK 109}

Dalam PSAK 109 terdapat 5 laporan keuangan seperti : Laporan Posisi Keuangan, Laporan Perubahan Dana, Laporan Arus Kas, Laporan Perubahan Aset Kelolaan, dan Catatan atas Laporan Keuangan. Dengan data yang diperoleh penulis, maka penulis mencoba membuat laporan keuangan masjid agung baiturrahman yang berdasarkan dengan PSAK 109. Tahap pertama, pihak pembuat laporan keuangan harus mampu menggolongkan akun-akun yang ada di masjid agung baiturrahman sesuai dengan komponen laporan keuangannya yang berdasarkan PSAK 109.

a. Laporan Posisi Keuangan

Dalam Laporan Posisi Keuangan (Neraca) ini menggambarkan keadaan posisi keuangan suatu entitas yaitu dalam kasus ini masjid. Dalam penyusunan Laporan Penyusunan Laporan Posisi Keuangan ini ada beberapa hal yang perlu diperhatikan:
1. Menggolongkan Asset yang dimiliki oleh Masjid Agung Baiturrahman, berikut ini aset masjid baiturrahman yang masuk ke dalam PSAK 109:

a. Kas dan Setara Kas:

- Shodaqoh Masyarakat

- $\quad$ Pedagang \& Masy. Pasar oleh Paguyuban Joko Tole

- Jasa Tabungan/Deposito

- Shodaqoh Instansi Vertikal/Polres

- Shodaqoh Perusahaan Swasta

- Kotak Jariyah Jumat

- Kotak Tabungan Akherat

- Shodaqoh Jamaah Ad Dhuha

- Infaq Pendidikan TK Baiturrahman

- Infaq Pendidikan TPQ Baiturrahman

- Shodaqoh Jamaah Hajat

- Hasil Wakaf

b. Perlengkapan

2. Aset tetap yang dimiliki oleh Masjid Agung Baiturrahman yaitu:

a. Pembangunan/Perbaikan Masjid

b. Peralatan

c. Inventaris

3. Kewajiban yang dimiliki oleh Masjid Agung Baiturrahman hanya kewajiban jangka pendek seperti yang dijelaskan oleh Bendahara umum:

"Disini untuk pemeliharaan masjid, saya itu bayarnya 1 bulan sekali, saya kan tidak selalu ada disini mas, jadi saya kasih wewenang ambil di toko barang-barangnya, saya sudah janji ditoko awal bulan akan bayar, selain itu percetakan, saya banyanya itu minimal 5 juta”.

a. Biaya Banner/Buletin (utang Biaya)

b. Biaya listrik air

c. Biaya cetak dan foto copy

d. Pembelian barang-barang bangunan (utang biaya)

4. Saldo dana, Masjid Agung Baiturrahman ini tidak terdapat saldo dana khusus.

"Untuk saldo dana disini tidak ada mas, semua masuk satu pintu disini semua,,,ehhh,,,,sumber dana masuk disini semua, cuma untuk pengeluarannya sendiri-sendiri".

\section{b. Laporan Perubahan Dana}

Laporan Perubahan Dana ini menampilkan semua penerimaan yang terjadi pada masjid agung baiturrahman dan semua pengeluaran masjid agung baiturrahman selama bulan tertentu. Dana zakat tidak masuk dalam laporan ini karena sudah ada lembaganya sendiri yang mengaturnya yaitu Lembaga Zakat Baiturrahman. Seperti yang dipaparkan oleh Bendahara umum:

"Untuk zakat itu berdiri sendiri sudah punya lembaga sendiiri di luar dari yayaysan, punya laporan sendiri, punya buku bank sendiri, karena disini menurut ketua dan tementemen zakat itu tidak bisa digunakan untuk yang lain-lain”. 


\section{c. Laporan Arus Kas}

Laporan arus kas ini menggambarkan aliran kas yang terjadi pada masjid agung baiturrahman. Dalam laporan arus kas. Masjid agung baiturrahman hanya terjadi arus kas dari aktivitas operasi saja, untuk arus kas dari investasi dan pendanaan tidak ada. Adapun arus kas dari aktivitas operasi yang dimilik oleh masjid agung baiturrahman yaitu:

a. Arus Kas Masuk dari Aktivitas Operasi:

- Shodaqoh Masyarakat

- Pedagang \& Masy. Pasar oleh Paguyuban Joko Tole

- Jasa Tabungan/Deposito

- Shodaqoh Instansi Vertikal/Polres

- Shodaqoh Perusahaan Swasta

- Kotak Jariyah Jumat

- Kotak Tabungan Akherat

- Shodaqoh Jamaah Ad Dhuha

- Infaq Pendidikan TK Baiturrahman

- Infaq Pendidikan TPQ Baiturrahman

- Shodaqoh Jamaah Hajat

- Hasil Wakaf

b. Arus Kas Keluar dari Aktivitas Operasi:

- Pembangunan/Perbaikan Masjid

- Jasa Penggalian Dana

- Konsumsi

- Biaya fotocopy

- BBM Operasional/Pulsa

- Mualim, Karyawan, Madin

- Jasa Transportasi

- Bea Pos/Surat

- ATK

- Perlengkapan

- Biaya Administrasi

- Sumbangan \& Sosial

- Informasi/Buletin/Banner

- Radio \& Operasional

- Jasa Kepelatihan \& Kependidikan

- Operasional Pengajian Ad Dhuha

- Operasional Komputer \& Alat-alat

- Biaya Listrik Air

- Biaya Pemeliharaan/Kebersihan

- Operasional Pengajian Ba'da Shubuh

- Operasional Sholat Jumat

- Operasional Pengajian Hajat

- Operasional RA Baiturrahman 1

- Operasional TPQ Baiturrahman

- Operasional RA Baiturrahman 2

- Pph Giro/Tabungan

- Administrasi Bank d. Laporan Perubahan Aset Kelolaan

Laporan Aset kelolaan ini memberikan manfaat jangka panjang. Karena Masjid Agung Baiturrahman tidak mempunyai Aset Kelolaan Maka tidak dibuatkan Laporan Aset Kelolaan.।

e. Catatan atas Laporan Keuangan

Laporan ini menggambarkan dan menjelaskan akun-akun yang terdapat dalam laporan posisi keuangan (neraca).

Misalnya kas dan setara kas berasal dara sumber mana saja.

\section{Proses Pelaporan Keuangan Masjid Agung Baiturrahman Berdasarkan PSAK 45}

PSAK 45 ini mengatur tentang organisasi Nirlaba, dimana dalam PSAK 45 terdapat 4 macam laporan keuangan seperti: Laporan Posisi Keuangan, Laporan Aktivitas, Laporan Arus Kas, dan Catatan atas Laporan Keuangan. Dalam penyusunan Laporan yang berdasarkan PSAK 45 yang terjadi pada Masjid Agung Baiturrahman hampir sama tahapannya dengan PSAK 109, tetapi yang membedakan hanya terdapat pada penggolongan aset saja. PSAK 45 ini terdapat beberapa penggolongan aset yaitu:

a. Aset neto tidak terikat adalah sumber daya yang penggunaannya tidak dibatasi untuk tujuan tertentu oleh penyumbang. Adapaun bila sumbangan tersebut terikat, itu berarti sumbangan tersebut dibatasi penggunaannya oleh penyumbang untuk tujuan tertentu.

b. Aset neto terikat temporer adalah sumber daya yang pembatasan penggunaanya dipertahankan sampai dengan periode tertentu atau sampai dengan terpenuhinya keadaan tertentu. Pembatasan penggunaan ini bisa ditetapkan oleh donatur maupun oleh organisasi nirlaba itu sendiri (misal: untuk melakukan ekspansi, atau untuk membeli aset tertentu).

c. Aset neto terikat permanen adalah sumber daya yang pembatasan penggunaannya dipertahankan secara permanen.

\section{Proses Pengumpulan Dana oleh Masjid Agung} Baiturrahman

Tujuan utama dari organisasi peribadatan atau keagamaan seperti masjid adalah untuk memberikan pelayanan dan menyelenggarakan seluruh aktivitas yang dibutuhkan maupun yang telah menjadi kegiatan ibadah rutin dalam organisasi keagamaan adalah melayani ummat secara baik. Meskipun tujuan utamanya adalah untuk pelayanan ummat, bukan berarti organisasi keagamaan tidak memiliki tujuan keuangan. Tujuan keuangan digunakan untuk mendukung terlaksananya tujuan pelayanan peribadatan yang memadai yang memenuhi standar sesuai dengan aturan dalam ajaran agama islam, serta menjunjung tujuan lainnya seperti tujuan sosial dan pendidikan, pendidikan disini yang dimaksud adalah TPQ untuk anak-anak, tentunya tujuan keuangan ini tidak untuk mencari keuntungan melainkan ke arah bagaimana membiayai kebutuhan beribadah ummat dalam tempat ibadah dan fungsi sosial keagamaan lainnya.

Proses Pencatatatn dan Pelaporan Keuangan Masjid Agung Baiturrahman Banyuwangi

Proses pencatatan keuangan yang diterapkan oleh Masjid Agung Baiturrahman yaitu menggunanakan metode cash 
basis. dimana Masjid Agung Baiturrahman mengakui pengaruh transaksi dan peristiwa lainnya pada saat kas atau setara kas diterima atau dibayar yang digunakan untuk pengakuan pendapatan, belanja dan pembiayaan. Setiap proses pemasukan muaranya yang pertama, dari program yang dimiliki oleh Masjid Agung Baiturrahman yaitu "full timer". Dimana full timer ini bertugas untuk melakukan rekapan awal semua pemasukan yang terjadi setiap minggu, setelah itu hasil dari rekapan full timer ini diserahkan ke Bendahara umum untuk dilakukan pencatatan keuangan serta dilakukan penyusunan laporan keuangan. Kedua, berasal dari kotak amal jumat yang langsung dihandle atau tangani oleh wakil bendahara 1. Terkait dengan penyusunan laporan keuangan Masjid Agung Baiturrahman Banyuwangi, ada empat tahap yang dilakukan oleh Bendahara umum. tahap pertama yang akan dilakukan oleh bendahara umum akan membuat kas bulanan atau tahunan. Kas yang dibuat oleh bendahara umum ini menggambarkan semua pemasukan dan semua pengeluaran yang terjadi selama periode tertentu. Tahap kedua, bendahara umum akan membuat kode rekening (akun) dimana kode rekening yang diterapkan oleh masjid agung baiturrahman ini ada dua macam yaitu: untuk pemasukan dibuatkan simbol angka (5-000) sedangkan untuk pengeluaran dengan kode rekening (7-000). Tahap ketiga, bendahara umum akan membuat jurnal atau pencatatan selama proses kas masuk dan kas keluar yang terjadi di masjid agung baiturrahman. Jurnal yang dibuat ini dengan format pemasukan dan pengeluaran yang dimiliki oleh masjid agung tersebut. Tahap keempat, setelah jurnal terbuat maka bendahara umum akan membuat buku pembantu yang mana buku pembantu ini menjelaskan pemasukan yang dimiliki oleh masjid agung baturrahman.

Berdasarkan pernyataan Bendahara umum Masjid Agung Baiturrahman keadaan laporan keuangan Masjid Agung tersebut lumayan baik dalam hal pengelolaan dan penyusunannya, tetapi laporan keuangan di Masjid Agung Baiturrahman Banyuwangi masih belum sesuai dengan PSAK 45 maupun PSAK 109, yang mana bapak Nur Hasan selaku Bendahara umum hanya menyusun Buku Kas Bulanan, Buku Jurnal, dan Buku Pembantu. Selain itu jurnal yang diterapkan disini masih belum menerapkan kolom Debet Kredit hanya dalam bentuk rekapan pemasukan dan pengeluaran. Berikut ini gambaran siklus akuntansi yang diterapkan oleh masjid Agung Baiturrahman Banyuwangi.

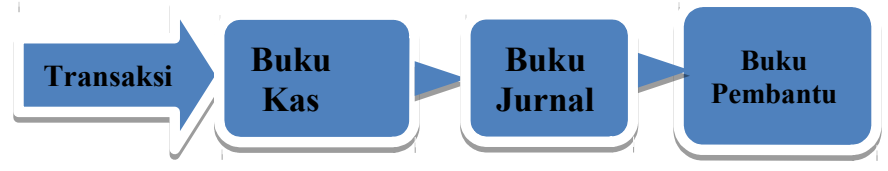

Gambar 1. Siklus Akuntansi Masjid Agung Baiturrahman

Sumber: Diolah sendiri

\section{Proses Pengumpulan Dana oleh Masjid Agung Baiturrahman}

Tujuan utama dari organisasi peribadatan atau keagamaan seperti masjid adalah untuk memberikan pelayanan dan menyelenggarakan seluruh aktivitas yang dibutuhkan maupun yang telah menjadi kegiatan ibadah rutin dalam organisasi keagamaan adalah melayani ummat secara baik. Meskipun tujuan utamanya adalah untuk pelayanan ummat, bukan berarti organisasi keagamaan tidak memiliki tujuan keuangan. Tujuan keuangan digunakan untuk mendukung terlaksananya tujuan pelayanan peribadatan yang memadai yang memenuhi standar sesuai dengan aturan dalam ajaran agama islam, serta menjunjung tujuan lainnya seperti tujuan sosial dan pendidikan, pendidikan disini yang dimaksud adalah TPQ untuk anak-anak, tentunya tujuan keuangan ini tidak untuk mencari keuntungan melainkan ke arah bagaimana membiayai kebutuhan beribadah ummat dalam tempat ibadah dan fungsi sosial keagamaan lainnya. Masjid Agung Baiturrahman mengumpulkan dananya dari masyarakat yang secara ikhlas dan sukarela berasal dari infaq, shodaqoh, kotak amal jumat, pengajian hajat, shodaqoh jama'ah Ad Dhuha dan lain-lain. Dengan kemandirian Masjid Agung Baiturrahman ini di tahun 2015 dapat penghargaan juara 2 sebagai masjid percontohan tingkat nasional karena kemandiriannya dan penghargaan juara 1 tingkat Jawa Timur karena kegiatannya yang kontinue.

\section{Proses Penyaluran Dana oleh Masjid Agung Baiturrahman}

Kegiatan Masjid Agung Baiturrahman selain mengumpulkan sumber dana juga menyalurkan sumber dananya untuk organisasi keagamaan maupun untuk fungsi sosial. Karena pengelola atau pengurus masjid atau yang biasa disebut takmir masjid dalam menggunaka dana ummat sesuai dengan ketentuan dalam ajaran agama dan kepentingan ummat beragama. Adapun kegiatan Masjid Agung Baiturrahman Banyuwangi diantaranya :

\section{Kegiatan Rutin Harian}

(Menyelenggarakan Ibadah Shalat Rawatib, Pengajian Ba'da Maghrib, Pengajian Ba'da Shubuh, Pendidikan (RA/TPQ/Madin).

\section{Kegiatan Rutin Mingguan}

(Menyelenggarakan Ibadah Shalat Jum'at, Sema'an AlQur'an, Pengajian Ad-Dhuha, Santunan Yatim-Piatu \& Fuqara-Masakin, Pengajian Hajat, Pendidikan (Perguruan Tinggi).

\section{Kegiatan Rutin Bulanan}

(Menyelenggarakan Pengajian Bulan Purnama (Khusus Muslimat)).

\section{Kegiatan Rutin Tahunan}

(Ibadah Shalat Hari Raya, Maulid Nabi Besar Muhammad SAW, Khitanan Massal, Isra' Mi'raj Nabi Besar Muhammad SAW, Training Shalat Khusyuk, Tadarus Al-Qur'an Raksasa, Nuzulul Qur'an, Pengajian Tasbih, Pembagian Zakat Fitrah, Penyembelihan \& Pembagian Daging Qurban, Harlah Masjid Agung Baiturrahman, Wisata Religi ke Makam Pendiri MAB \& Para Wali, Tahlil Akbar \& Pengajian Bulan Berkaca).

\section{Simpulan}

Dari pembahasan yang telah diurakan sebelumnya dapat kita tarik dua kesimpulan. Kesimpulan pertama adalah bahwa Masjid Agung Baiturrahman telah melakukan pelaporan keuangan yang lumayan baik yaitu: pertama, dengan adanya pembagian tugas atau job description setiap pengurus seperti bendahara 1, bendahara 2, dan bendahara 3. Kedua, laporan yang dibuat oleh bendahara sudah tersistem yaitu dengan menggunakan excel dan program full timer. Ketiga, masjid 
agung baiturrahman sudah menerapkan kode rekening berdasarkan kegiatan yang dialami. Keempat, dengan diterapkannya kode rekening tersebut maka ada pemisahan dalam pengeluaran kas seperti pengajian hajat. Kelima, dengan adanya pemasukan-pemasukan dari berbagai sumber maka bendahara umum membuatkan buku pembantu supaya mempermudah dalam melakukan rekapitulasi.

Kesimpulan kedua adalah Masjid merupakan suatu organisasi nirlaba yang mana dalam organisasi tersebut banyak sumber dana yang masuk dari berbagi pihak, banyaknya sumber dana yang terkumpul digunakan untuk berbagai kegiatan yang ada di Masjid. Dengan banyaknya kegiatan yang ada di Masjid Agung Baiturrahman maka perlu dibuatkan laporan keuangan yang lebih terstruktur guna mempermudah dalam mempertanggung jawabkan kepada masyarakat maupun kepada pemerintah. Oleh karena itu peneliti mencoba merekonstruksi laporan keuangan Masjid sesuai dengan peraturan PSAK 109 dan PSAK 45 yang dapat dijadikan panduan untuk menyusun laporan keuangan Masjid yang lebih transparan dan akuntabel. Dengan disusunnya laporan keuangan Masjid yang lebih transparan yaitu sesuai dengan PSAK maka akan memberi kepercayaan atas pengelolaan keuangan tresebut kepada para donatur.

\section{Referensi}

Ikatan Akuntan Indonesia (IAI). 2017. Exposure Draft Standar Akuntansi Keuangan Entitas Mikro, Kecil, dan Menengah (ED-SAK EMKM). Dewan Standar Akuntansi Keuangan, Jakarta.

Indriantoro, Bambang S. 2014. Metodologi Penelitian Bisnis. Edisi Pertama. BPFE-Yogyakarta, Yogyakarta.
Miles, M. B. \& Huberman, A. M. 1992. Analisis Data Kualitatif: Buku Sumber Tentang Metode Baru. UI Press, Jakarta.

Romney, Marshall B., Steinbart, Paul J. 2012. Accounting Information Systems. Twelfth Edition. Global Edition, Pearson Education Limited.

Sugiyono, 2012. Metode Penelitian Kuantitatif, Kualitatif dan R\&D. Alfabeta. Bandung.

Widodo, Ahmad Bayu. 2014. Perancangan Basis Data Akuntansi Berbasis Microsoft Access untuk Mendukung Sistem Informasi Akuntansi pada Pembukuan dan Pelaporan Keuangan Entitas Usaha Mikro Kecil dan Menengah (UMKM). Fakultas Ekonomika dan Bisnis. Universitas Gadjah MadaAndasari, Pipit Rosita. 2016. Laporan keuangan organisasi nirlaba. Jurnal ekonomi universitas kediri. Vol. 1, No. 2, Hal. 143-152

Andikawati, Desy. 2014. Laporan Keuangan Masjid. Jurnal Akuntansi Universitas Jember. Vol. 2. No. 2

Ayub et al. 2011. Akuntansi Sektor Publik. Salemba Empat

Dewan Masjid Indonesia. 2012

http://www.siperubahan.com/read/436/Ketika-Masjid-MembutuhkanSentuhan-Para-Ekonom-Syariah

Ikatan Akuntansi Indonesia. 2015. PSAK No. 45 , No. 109. Ikatan Akuntansi Indonesia, Jakarta.

Indriantoro, Nur dan Bambang Soepomo. 2014. Metodologi Penelitian Bisnis: Untuk Akuntansi Dan Manajemen. Edidi Ketiga. Yogyakarta: BPFE UGM

Jusuf, Al. Haryono. 2005. Dasar-dasar Akuntansi. Jilid 1. Sekolah Tinggi Ilmu Ekonomi YKPN, Yogyakarta.

Kurniasari, wiwin. 2011. Transparansi Pengelolaan Masjid dengan Laporan Keuangan Berdasarkan PSAK 45. Jurnal Muqtasid. Vol. 2 No. 1

Pralebda, Gatot. 2013. Pengelolaan Dana Masjid yang Amanah. Online. (http:www.almuqarrabinwp.com)

Wijangsongko, Lingga Jenar. 2014. Implementasi akuntansi dalam organisasi keagamaan. Jurnal Universitas Pembangunan Nasional JATIM. Vol. 1, No. 3

Yani, Ahmad. 2007. Panduan Mengelola Masjid, Jakarta: Pustaka Intermasa. 